\title{
THE BROKEN BODY IN ELEVENTH TO THIRTEENTH- CENTURY ANGLO-SCANDINAVIAN LITERATURE
}

\author{
Matthew Firth*
}

\begin{abstract}
Anglo-Scandinavian literary and legal texts give evidence of two cultures which shared similar attitudes to punitive acts of violence; whether as literary trope or legislative recourse, deliberate mutilation was a familiar form of retribution. Why this is the case is not always clear within the context of the texts in which such episodes are narrated, or punishments prescribed. Anglo-Saxon England and Scandinavia had a long history of cultural contact. Both were Germanic cultures that, by the time their laws, narratives, and histories were recorded, were also Christian cultures. Moreover, Scandinavians had been visiting English shores for three-hundred years from the eighth century, raiding and settling, culminating in 1017 in the ascension of the Danish prince Cnut to the English throne. At each point of cultural contact, the exchange of ideals and values may have aided in facilitating acculturation as it related to societal attitudes to the body. By analysing selections from legal texts, Anglo-Saxon hagiography, and Íslendingasögur (Icelandic family sagas) that portray or engage with acts of deliberate mutilation, this paper explores the origins and evolution of shared Anglo-Scandinavian attitudes to punitive violence.
\end{abstract}

Keywords: Anglo-Saxon History, Scandinavian History, Medieval Law, body, mutilation, feud.

Narrative is particularly fertile ground for research into societal ideologies and their inter-cultural transmission or common origin. By analysing the stories told within cultures, one can identify the traits that a given culture privileged, as well as the behaviours that they scorned. Indeed, within narrative, topoi that represent distinct social mores are frequently made easier to access; as Hayden White states in his study of narrative and the transmission of history, "we may not be able to comprehend specific thought patterns of another culture, but we have relatively less difficulty understanding a story coming from another culture." Yet "less difficulty" does not equate to "little difficulty" and some tropes that recur throughout Anglo-Scandinavian literature in the eleventh-thirteenth centuries seem at first glance quite alien. One such example is the motif of punitive mutilation, the focus of this paper. While English and Scandinavian sources reflect the evolution of independent social, legal, and literary cultures, extant law codes and

* College of Humanities, Arts and Social Sciences, Flinders University, Sturt Road, Bedford Park, South Australia, 5042, matthew.firth@ flinders.edu.au.

${ }^{1}$ Hayden White, The Content of the Form: Narrative Discourse and Historical Representation (Baltimore 1991) 1.

Comitatus 50 (2019) 45-75. 
narrative texts display evidence of shared attitudes to punitive acts of violence. Indeed, the cultural distinctiveness of these textual traditions makes the common treatment of punitive mutilation within them conspicuous: an identifiable Anglo-Scandinavian cultural affinity. Such inter-cultural exchange may have derived from numerous sources. Anglo-Saxon and Scandinavian societies had common Germanic cultural origins; shared three-hundred years of direct contact and settlement from the eighth century; shared a king in Cnut between 1017 and 1035; and, by the time these narratives were committed to text, shared the Christian religion. Facilitated by an examination of AngloScandinavian legal culture and, more particularly, a comparative analysis of Icelandic and Anglo-Latin literary texts, this paper considers what role these points of cultural contact had in promoting acculturation as it related to societal attitudes to vengeance inscribed upon the body. In so doing, it questions to what degree common attitudes to punitive mutilation may demonstrate significant AngloSaxon assimilation of Scandinavian cultural values leading into the eleventh century, and to what degree the phenomenon should be attributed to shared Germanic heritage or shared religion.

Granted the distinctive nature of English and Scandinavian literary traditions in the period under examination, identifying appropriate literary types to facilitate comparative analysis is not without challenge. The Anglo-Saxon and Scandinavian literary corpora are fraught with chronological complexities relating to the distance of textual record from the events described and the intrusion of external literary traditions, born of the circumstances in which the cultures embraced literacy. To a large extent literacy accompanied Christianity in AngloSaxon England and much of Scandinavia, unusually manifesting a vernacular literary tradition (though Latin learning was ubiquitous to both as literate cultures, with Latin texts increasing in prevalence over time). However, though Christianity asserted itself as the religion of the Anglo-Saxons throughout the seventh century, the conversion of Scandinavia only began in earnest in the late tenth century. ${ }^{2}$ On an

\footnotetext{
${ }^{2}$ For the Christianization of England see: Anglo-Saxon Chronicle E 604, 616-627, in Two of the Saxons Chronicles Parallel (ASC), ed. Charles Plummer (Oxford 1892) 2123. English translation from: The Anglo-Saxon Chronicle, ed, and trans. Dorothy Whitelock (London 1965); Bede, Ecclesiastical History of the English People, 1.xxv, ed. Bertram Colgrave and R.A.B. Mynors (Oxford 1969) 72-77. For the Christianization of
} 
individual level such dating cannot be definitive, Christians were present throughout all regions in the North Sea prior to any officially promulgated conversion by ruling elites, yet these dates do align with the extant texts. Anglo-Saxon narrative sources appear from the eighth century with Old English literature achieving something of a zenith through the ninth and tenth centuries, while the first Scandinavian texts date to the twelfth century and become more common in the form of saga narrative through the thirteenth century. ${ }^{3}$ Yet, while most extant saga texts postdate the earliest Anglo-Saxon texts by as much as three centuries, they frequently take as their inspiration the histories and tales of ninth-eleventh-century Scandinavia.

For the purpose of a comparative analysis, there is only one type of English literature temporally relatable in both authorship and setting to these Scandinavian narrative sources: eleventh- and twelfth-century Anglo-Latin hagiographies narrating Anglo-Saxon saints' lives. Composed contemporaneously to the sagas of Icelanders, these saints' lives too were inspired by the events of the ninth-eleventh-centuries. Both corpora are fundamentally literary in nature, reflecting a nostalgic narrative mode that imbues a constructed past with didactic idealism and, importantly, within this context contain locatable instances of punitive mutilation. It is my suggestion here that, despite the common usage of the motif across the literature, the reading of hagiography and saga side-by-side demonstrates that a divide in cultural attitude to punitive mutilation is identifiable, resulting from both differences in culture and literary intent. For, while the authors of the Icelandic sagas examined herein reluctantly deployed terse descriptions of punitive mutilation as an aberrant event within a complex social framework, the English hagiographers relished in graphic descriptions of brutal torture.

\section{NARRATIVE FRAMEWORKS: \\ ENGLISH HAGIOGRAPHY AND ÍSLENDINGASÖGUR}

As a literary genre, hagiography is built upon events and tales of the past, overlaid with didactic motifs intended for an audience coetaneous

Scandinavia see: Ari Porgilsson, Íslendingabók vii, trans. Siân Grønlie (London 2006) 7 9; Saxo Grammaticus, Gesta Danorum, x.11.3-6, ed. Karsten Friis-Jensen, trans. Peter Fisher, vol. 1 (Oxford 2014) 716-721.

${ }^{3}$ Elaine Treharne, ed., Old and Middle English c. $890-$ c. 1450: An Anthology $(O \& M E), 3^{\text {rd }}$ edn. (Oxford 2010) $\mathrm{xx}-\mathrm{xxv}$; William Ian Miller, Bloodtaking and Peacemaking: Feud, Law, and Society in Saga Iceland (Chicago 2009) 42-45. 
with the written texts. Arguably, this description is also apt for Íslendingasögur - the corpus of Icelandic family sagas. However, while the didactic nature of hagiography is that of moral instruction directly informed by Christian theology and custom, that of Íslendingasögur is something closer to what we would recognize as historically motivated (or, perhaps more accurately, a product of antiquarianism). In part record of transmitted oral narrative, in part authorial invention, Íslendingasögur relate histories and legends of Iceland's principle families with a view to preserving (and fabricating) a unifying Icelandic identity. Within this narrative framework, Iceland and Icelanders become integral to the political landscape of ninth-eleventhcentury Northern Europe and the legal and moral codes of early NorseIcelandic societies are venerated. ${ }^{4}$ The hagiographies of post-Conquest England are no less politically motivated, being similarly retrospective and styled to audience expectations at the time of authorship. The appropriation of Anglo-Saxon saints by the Norman church in England facilitated the integration of the Anglo-Saxon church within the Norman ecclesiastical hierarchy, while also providing coherent narratives promoting regional cults..$^{5}$ These accounts inflate the importance of the saint within their own political landscape and augment both their suffering and sanctity as exemplars of right Christian behaviour as promoted by the eleventh- and twelfth-century church in England. Though composed in part to entertain, neither saints' lives nor sagas are purely intended as such and, in their didactic narrative elements, it is possible to identify cultural markers indicating specific social mores.

The somewhat narrow focus upon Anglo-Latin hagiographies of the late-Anglo-Saxon and early-Anglo-Norman periods does preclude examination of such iconic texts such as Beowulf and the Old English elegies. Old English poetics certainly contain some fascinating examples of mutilative violence, such as Beowulf tearing off Grendel's arm, or the anthropomorphic cross of the Dream of the Rood describing

\footnotetext{
${ }^{4}$ Axel Kristinsson, "Lords and Literature: The Icelandic Sagas as Political and Social Instruments," Scandinavian Journal of History (2003) 7-10.

${ }^{5}$ Catherine Cubitt, "Sites and Sanctity: Revisiting the Cult of Murdered and Martyred Anglo-Saxon Royal Saints,” Early Medieval Europe 9, iss. 1 (2000) 70-71.
} 
the nails entering its wood as they are hammered through Christ. ${ }^{6}$ Yet such imagery can rarely be defined as punitive mutilation (a term to which I will shortly return). Additionally, setting aside the dating controversies surrounding Beowulf, the majority of the Old English poetic corpus in its genesis predates the period of most significant Scandinavian contact, prohibiting their use in an analysis of AngloScandinavian acculturation. ${ }^{7}$ Though the Scandinavian fornaldarsögur (legendary sagas) may match Beowulf for epic scope, and the Old Norse Poetic Edda may even eclipse the Old English elegies, the Scandinavian and Old English texts are separated by centuries. Taken as a whole, the mythologized worlds, fictive poetics, and proverbial wisdom of early Anglo-Saxon texts comprise a unique corpus of literature unparalleled by Scandinavian sources. In contrast, though the surprisingly secular Íslendingasögur narratives pertaining to early medieval Iceland and Anglo-Latin hagiographies relating the lives of Anglo-Saxon saints may seem an odd match, their temporal compatibility in both authorship and content has been noted. Further, if the presence of a plausible, if embellished, historicity is taken as a requirement for an examination of evolving societal attitudes, the Íslendingasögur and hagiographies explored here are historically locatable.

This veneer of historicity is something that has been given some valuable consideration by John Frankis and Susanne Kries in accounts of the murder of Alfred Etheling. ${ }^{8}$ A historically attested figure, Alfred was mutilated and murdered in the power struggles that followed Cnut's death in 1035. Though he was never canonized, Alfred's murder was almost immediately portrayed as martyrdom; in its 1036 entry, the C-text of the Anglo-Saxon Chronicle declares of the event that, "no worse deed was done in this land." ${ }^{9}$ Taking as the basis for his analysis a topos of evisceration that he terms "the fatal walk," Frankis identifies

\footnotetext{
${ }^{6}$ Beowulf xii, in $O \& M E$ (n. 3 above) 204-207; The Dream of the Rood 46-49, in $O \& M E$ (n. 3 above) 122-123.

${ }^{7}$ Ashley Crandell Amos, Linguistic Means of Determining the Dates of Old English Literary Texts (Cambridge 1980) 1, 9-12.

${ }^{8}$ John Frankis, "From Saint's Life to Saga: The Fatal Walk of Alfred Ætheling, Saint Amphibalus and the Viking Bróðir," Saga Book 25 (2001) 121-137; Susanne Kries, "English-Danish Rivalry and the Mutilation of Alfred in the Eleventh century Chronicle Poem The Death of Alfred," Journal of English and German Philology 104 (2005) 31-53. ${ }^{9}$ ASC C 1036 (n. 2 above) 158-159.
} 
its first appearance in Alfred's story in Geffrei Gaimar's twelfthcentury hagiographical rendition of the murder:

Then they took Alfred prisoner and brought him to Ely where they had his eyes put out. They made him walk around a stake, having first pulled out his large intestine. With goads that they had made they drove him round and round, in order to strip out his intestine until finally he could no longer stay on his feet. ${ }^{10}$

He then correlates this with the appearance of the motif in an unrelated episode from the thirteenth-century Icelandic Njáls saga:

Úlf Hræða cut open his belly and led him around an oak tree and in this way pulled out his intestines. Broðir did not die until they were all pulled out of him. ${ }^{11}$

Though considering the fatal walk to be late additions to both narratives, Frankis believes both Scandinavian and Anglo-Saxon expressions of the motif have common origins in an earlier period. ${ }^{12}$ In her turn, Kries explores the tension between English and Danish elites in an immediate post-Cnut England through English accounts of the cetheling's mutilation and death (in which he is blinded only), composed closer to the time of the event. Grounding Alfred's murder historically, Kries identifies Cnut's reign as a cultural nexus in the transition from capital to corporal punishment, and thereby establishes that, while such cases of political mutilation may have been extrajuridical, they fall "within the bounds of Anglo-Saxon law."." Taking into account the literary aspects of the Chronicle entry, Kries asserts that the entry provided a rhetorical platform from which the chronicler could interpret and communicate the complicated political interplay inherent in the event. ${ }^{14}$ Thus, though the mutilation of Alfred takes on aspects of legal tradition and hagiography, much of its value resides in its portrayal of tangible political circumstance. As the son of Æthelred,

\footnotetext{
${ }^{10}$ Geffrei Gaimar, Estoire des Engleis-History of the English 4819-4842, ed. and trans. Ian Short (Oxford 2009) 262-263.

${ }^{11}$ Brennu-Njáls saga 157 - Íslenzk fornrit xii, ed. Einar Ólafur Sveinsson (Reykjavík 1997) 453. English translation from: Njal's saga 157, trans. Robert Cook, in The Complete Sagas of Icelanders, vol. 3 (Reykjavík 1997) 214.

${ }^{12}$ Frankis, "From Saint's Life to Saga" (n. 8 above) 124-130, 134-135.

${ }^{13}$ Kries, "English-Danish Rivalry" (n. 8 above) $37-41,53$.

${ }^{14}$ Ibid. $51-53$.
} 
Alfred was an Anglo-Saxon claimant to the throne with a lineage that predated the Danish dynasty, his death was understood as an act undertaken on behalf of the ruling Danes in order to neutralize a rival for power. ${ }^{15}$ In contrast, the use of the fatal walk in Njáls saga contributes a rather jarring fictional element into a known historical event (the Battle of Clontarf) and, more widely, into a saga notable for an aesthetic historical realism. As a borrowing from hagiography, Frankis suggests the fatal walk can be read as a didactic exemplar Broðir, pagan and apostate, suffers like a saint, but without hope of redemption or salvation. The graphic imagery of the fatal walk itself is to a degree atypical of Íslendingasögur, representing the concern of some later saga authors to present instructional Christian topoi alongside or in place of those representing specifically Icelandic social values. ${ }^{16}$ The presence of the fatal walk in Njáls saga, then, clearly indicates some awareness of hagiographical traditions within saga literature (though not an antithetical relationship). It does not, however, imply the identical use of such motifs. Located within the context of Clontarf, the fatal walk of Njáls saga is not a trial of an innocent saint, but vengeance for a wicked deed, demonstrating some contrast between saint's life and saga.

The Norse sagas are conventionally classified into five narrative traditions: Konungasögur (king's sagas); Íslendingasögur (Icelandic family sagas); Fornaldarsögur (legendary sagas); Samtíðarsögur (sagas of contemporary history); and Riddarasögur (chivalric sagas). ${ }^{17}$ These are modern distinctions, yet useful. The textual recording of most sagas is broadly contemporaneous, dating primarily to the thirteenth century, yet each saga "genre" is a product of unique influences and authorial intent. Thus, where common social mores can be identified across the resultant divergent literary frameworks, it is logical to consider these as preserving the cultural attitudes of earlier generations. ${ }^{18}$ Further, it seems likely that this is evidence of the transmission of oral memory originating in earlier centuries. The

\footnotetext{
${ }^{15}$ See for example: ASC C, D 1036 (n. 2 above) 158-159; William of Malmesbury, Gesta Regum Anglorum (G.Reg) ii.188.5-6, ed. and trans. R.A.B. Mynors, R.M. Thomson and M. Winterbottom, vol. 1 (Oxford 1998) 336-339.

${ }^{16}$ Frankis, "From Saint's Life to Saga" (n. 8 above) 134-135.

${ }_{17}$ Margaret Clunies Ross, The Cambridge Introduction to Old Norse-Icelandic Literature (Cambridge 2010) 29-31.

${ }^{18}$ Miller, Bloodtaking and Peacemaking (n. 3 above) 44-47.
} 
paucity of punitive mutilation within native Scandinavian literature, therefore, suggests there was little social sanction for such retributive action inherent within pre-literate Scandinavian cultures. ${ }^{19}$ "The famous association of viking with violence," Guy Morris has asserted, "stems almost entirely from non-Scandinavian records"; there is no clear evidence for cultural acceptance of punitive mutilation in Scandinavian narrative sources predating the thirteenth century. ${ }^{20}$ Where the trope does appear, the Konungasögur and Íslendingasögur are more likely to show evidence of eleventh-century attitudes to the practice than other genres. The Riddarasögur represent borrowings from the medieval romances of Western Europe and are thus culturally and chronologically problematic for the purpose of establishing eleventh-century social mores. Despite being adapted to Old Norse language and narrative conventions, the Riddarasögur have origins independent of the historical evolution of saga tradition and represent little of endemic Scandinavian culture. ${ }^{21}$ In contrast, the Samtíðarsögur (usually translated as "contemporary sagas") are culturally harmonious sources composed shortly after the events they narrate, primarily serving to record twelfth- and thirteenth-century Icelandic history. Though their authorship is coeval with many Íslendingasögur, these preserve Icelandic narratives of the ninth-eleventh centuries, albeit with the attendant anachronisms of two centuries of societal evolution, while the Samtíðarsögur are temporally grounded in historical events. ${ }^{22}$ As such, though the Samtíðarsögur are excellent near-contemporary accounts of politics and prevailing cultural norms, they cannot be read as sources of earlier Scandinavian history.

It must similarly be said of the Fornaldarsögur that they are not direct sources for early Scandinavian history, though they do reflect upon a distant past. Also recorded around the thirteenth century, the

${ }^{19}$ Larissa Tracy, Torture and Brutality in Medieval Literature: Negotiations of National Identity (Cambridge 2015) 129-131.

${ }^{20}$ Guy A. E. Morris, "Violence and Late Viking Age Scandinavian Social Order," in Violence and Society in the Early Medieval West, ed. Guy Halsall (Woodbridge 1998) 141.

${ }^{21}$ Clunies Ross, Old Norse-Icelandic Literature (n. 17 above) 30; Jónas Kristjánsson, Eddas and Sagas, trans. Peter Foote (Reykjavík 2007) 22-24; Jürg Glausser, "Romance (translated Riddarasögur)," in A Companion to Old Norse-Iceland Literature, ed. Rory McTurk (Oxford 2005) 374-378.

${ }^{22}$ Úlfar Bragason, "Sagas of Contemporary History (Sturlunga saga): Texts and Research," in Old Norse-Iceland Literature (n. 21 above) 427-428, 431-433. 
Fornaldarsögur are folkloric tales in which heroes and gods shape the world of pre-historic Scandinavia. ${ }^{23}$ Jónas Kristjánsson casts doubt upon any remnant historicity within the Fornaldarsögur, stating that "traditions from the earlier periods had either dried up or swelled into exaggerate folklore." ${ }^{24}$ Kristjánsson is right to be critical of the Fornaldarsögur as evidence of historical events. It is, however, too critical to deny the Fornaldarsögur any sociological value within their narrative structure; familiar tropes are present and explicit. Stefan Hall has noted instances of punitive mutilation in the Fornaldarsögur, deployed as a tool to augment personal honour rather than a visceral spectacle. ${ }^{25}$ It is a revealing attitude to the practice, reminiscent of hagiography; punitive mutilation loses its agency when perpetrated upon a hero who dies well, or is later able to enact vengeance. ${ }^{26}$ Yet the parallel is not exact, and the motive of the literary topos within its narrative is distinct between the traditions. While the hagiographer places torture outside legal provision, providing detailed torture scenes in which the brutality augments the saint's sanctity, the saga author avoids graphic descriptors, being more interested in placing the motivations for and repercussions of an act of mutilation within a legal and social framework. ${ }^{27}$ Though expressions of the trope in the Fornaldarsögur are explicit, they occur within a mythic world and historical touch points are difficult to locate. As such, for the purpose of correlative analysis, Íslendingasögur are uniquely commensurate with Anglo-Saxon hagiography as primarily narrative sources in which history, folklore, and religious allegory are blended.

\section{DEFINING "Punitive Mutilation"}

Having provided some historical background and scholarly context for the narrative types that form the focus of this discussion, it remains to delineate what is intended by the term "punitive mutilation." In identifying examples of cross-cultural attitudes to the treatment of the

\footnotetext{
${ }^{23}$ Kristjánsson, Eddas and Sagas (n. 21 above) 22-24.

${ }^{24}$ Ibid. 23.

${ }^{25}$ Stefan Thomas Hall, "Last Laughs: Torture in Medieval Icelandic Literature," Enarratio 16 (2009) 97.

${ }^{26}$ Ibid. 100-101, 105-106; Tracy, Torture and Brutality (n. 19 above) 31-35.

${ }^{27}$ Tracy, Torture and Brutality (n. 19 above) 31-35; Fredrik J. Heinemann, "Hrafnkels saga Freysgoða and Type-Scene Analysis," Scandinavian Studies 46 (1974) 105.
} 
body, I focus on accounts where the act of mutilation is not the intended vehicle for an alternative outcome, such as torture to exact confession, but in which the torture itself is the punishment. Thus, my focus is not on mutilation as an element of judicial process, but as an allowable outcome or mandated sentence within a legal framework. Moreover, as defined herein, "punitive mutilation" does not extend to retributive execution, murder, or unintended injury in which the intent to torture or mutilate are not evident. This is not to say that punitive mutilation may not result in execution or murder, yet in such cases the mode of death will clearly entail torturous intent. The evisceration of Broðir, undertaking the fatal walk in Njáls saga provides an example of this. The cessation of Broðir's life is peripheral to the gruesome tableau of him proceeding around the impromptu post, dying slowly as his entrails wind out of his body. ${ }^{28}$ The executioner's intent is clearly to torture his enemy to death, and the saga author does not intend to relay the death of Broðir so much as he intends to relay the brutal nature of the torture that facilitated it. ${ }^{29}$ Intent to torture is one of the two defining factors in what is here deemed as punitive mutilation, the other being retributive motivation.

To appropriately assess retributive motivation within social conceptions of punitive mutilation, it is important to note - particularly in the context of Íslendingasögur, a literature overtly concerned with the function of law - that the term "punitive mutilation" is not intended to restrict the discussion to examples where legislative provisions for mutilation as a corrective exemplar are evident. Punitive mutilation can equally be extra-juridical, particularly in Germanic social structures in which feuds between rivals could rapidly escalate and acts of retributive justice take on an aspect of spontaneous revenge. This is the kind of event demonstrated in a famous passage from the Icelandic Hrafnkels saga Freysgoða in which the eponymous figure and his men are hung by a rope threaded through holes cut into their heels:

\footnotetext{
${ }^{28}$ Brennu-Njáls saga 157 (n. 11 above) 453.

${ }^{29}$ John Frankis, "From Saint's Life to Saga" (n. 8 above) 121-124.
} 
Then they took out their knives, pierced holes through the men's heels behind the tendons, and dragged the ropes through these holes. They threw the rope over the beam, and strung the eight of them up together. ${ }^{30}$

Unlike Broðir, Hrafnkel survives to later take revenge. It is unusual within saga narrative that an act of mutilation is definitive within an inter-family revenge cycle and, as such, despite the brutal punishments meted out to Broðir and Hrafnkel, torture is highly unusual within these texts. Even when the act seems justified within the interchanges of feud, it remains that such methods are not codified punishments within Icelandic law and the reader is rarely asked to empathize with the torturer. Thus the author of Hrafnkels saga seems to be implying judgement upon the perpetrators of the act; however, Hrafnkel had been previously condemned to outlawry and, having caught such an outlaw, it is not clear that the men undertaking the retribution are acting outside juridical provision. ${ }^{31}$ By which it can be seen that the line between juridical and extra-juridical mutilation is not necessarily as clear as a modern reader would expect.

While these definitional examples come from the Scandinavian literary context, incidents that demonstrate intentional, retributive mutilation are similarly locatable in Anglo-Saxon saints' lives. In a contrasting but equally conflicted narrative to that of Hrafnkels saga, Translatio et miracula S. Swithuni (written c. 974 by Lantfred, a monk of Winchester) relates the case of a wrongly accused man who has "his eyes put out, his hands cut off, his ears torn off [and] his nostrils carved open." 32 In what is a commentary on the harsh nature of such laws, Lantfred declares it to have been enacted by "wicked executioners," and ensures the reader understands not only the man's physical incapacity, but the burden and punishment he represents as a nonfunctioning member of his household. ${ }^{33}$ Though the events leading to mutilation, the methods of mutilation, and the authority to mutilate vary

\footnotetext{
${ }^{30}$ Hrafnkels saga Freysgoða 11 - Íslenzk fornrit xi, ed. Jón Jóhannesson (Reykjavík 1954) 120-121. English translation from: The Saga of Hrafnkel Frey's Godi 11, trans. Terry Gunnell, in The Complete Sagas of Icelanders, vol. 5 (Reykjavík 1997) 214.

${ }_{31}$ R.D. Fulk, "The Moral System of Hrafnkels saga Freysgoða," Saga Book 22 (1986-1989) 22; Hall, "Last Laughs" (n. 25 above) 98.

${ }^{32}$ Lantfred, Translatio et miracula S. Swithuni, 26, in The Cult of St Swithun, ed. and trans. Michael Lapidge (Oxford 2003) 310-313.

${ }^{33}$ Ibid.
} 
greatly between Hrafnkel and the unnamed man, in both cases the punishment of physical torment is retributive and intentional. It is these factors that best define "punitive mutilation" within this discussion: an act of torture that is, at once, retributive and intentional.

\section{THE BODY AND LAW}

Legal codes necessarily form a part of the cultural environment in which narratives were constructed, and it is a central assertion of this paper that didactic story-telling operates within recognizable social structures. As seen in the examples of Icelandic saga and English hagiography above, these stories are not cultural outputs isolated from the function or intended function of the law. Codified laws reflect the desired behavioural norms of a ruling administration; however, the existence of a law neither provides evidence of its widespread promulgation, nor any substantive application in practice. In contrast, narrative recounts actions that do demonstrate societal attitudes to punitive mutilation in action, though it remains that such deeds can be read as either "legal" or "illegal" in societies where centralized lawcodes exist. The frameworks within which societies were intended to operate, and those behaviours that legislators deemed taboo in establishing that legal framework, are demonstrative of the specific problems regions were deemed to be facing. Within post-Roman Western Europe, regional social structures developed out of the interplay between residual Roman law and Germanic tradition, with each region's law-codes representing a unique blend of the two traditions dependent upon that territory's experience of acculturation. ${ }^{34}$ Thus, while Roman legal processes did enter legislative programs of Scandinavia and England, their isolation made for a slower process, and they were longer able to retain commonalities in the intent of law, governance, and social mores of a mutual Germanic inheritance. ${ }^{35}$ Yet similarities in legal and narrative traditions may also extend from contact acculturation or royal imposition, and evidence of Scandinavian cultural attitudes within Anglo-Saxon sources cannot be neatly

${ }^{34}$ James A. Brundage, Law, Sex, and Christian Society in Medieval Europe (Chicago 1987) 124-125.

${ }^{35}$ Lisi Oliver, The Body Legal in Barbarian Law (Toronto 2011) 8-14; Patrick Wormald, The Making of English Law: King Alfred to the Twelfth Century, vol. 1 (Oxford 1999) 96-97. 
categorized into any one mode of transmission. While there is little debate that commonalities exist in law-codes across eleventh- and twelfth-century North-Western Europe, how such material can be read for evidence of inter-cultural transmission of ideas is under constant reevaluation.

The interrelation of body and law in medieval Europe, including Anglo-Saxon England, has been robustly theorized over recent years. Anglo-Saxon law-codes are unique as vernacular laws from the earliest surviving code of Æthelberht of Kent (c. 602) through to the Norman Conquest, though in content identifiably of the Germanic tradition, at least in origin. ${ }^{36}$ Lisi Oliver provides extensive commentary on punishment traditions within "barbarian codes" which can either mandate compensation for extra-legal damage to the body or legitimize legal damage to the body as a criminal sentence. ${ }^{37}$ Compensation for extra-legal mutilation and provision for legal mutilation represent different societal attitudes to the body, and it is unusual for both to be present in a single code. Athelberht's Code is representative of the compensatory model, delineating monetary penalties (wergild) for acts of mutilation, with little consideration given to the intent of the perpetrator, and no systematized provision for reciprocal mutilation. ${ }^{38}$ It is not an oversimplification to characterize early wergild laws as primarily intended to prevent feud cycles. In her article "The Body in Early Anglo-Saxon Law," Mary Richards makes particular note of the categorization of wergild clauses relating to mutilation within Ethelberht's Code: compensation for visible mutilation is set substantively higher than for discreet injuries. ${ }^{39}$ Richards argues that this is a tacit recognition of the dual nature of a visible wound: the detriment of physical capacity, and the detriment of agency or reputation through the visual inscription of the wound upon the

\footnotetext{
${ }^{36}$ Athelberht's Code, in Die Gesetze der Angelsachsen, vol. 1, ed. Felix Liebermann (Halle 1903) 3-8.

${ }^{37}$ Oliver, The Body Legal (n. 35 above) 8-25; Lisi Oliver, "Protecting the Body in Early Medieval Law," in Peace and Protection in the Middle Ages, ed. T.B. Lambert and David W. Rollason (Durham 2009) 60-77 (especially 71).

${ }^{38}$ See for example: Athelberht's Code 8, 33-71, 79-81 in Die Gesetze der Angelsachsen (n. 36 above) 3-8.

${ }^{39}$ Mary P. Richards, "The Body as Text in Early Anglo-Saxon Law," in Naked Before God: Uncovering the Body in Anglo-Saxon England, ed. Benjamin C. Withers and Jonathon Wilcox (Morgantown 2003) 97-115.
} 
victim. $^{40}$ In a society comprised of disparate agricultural communities, a wound that hindered an individual's ability to contribute to the daily function of their community resonated throughout the whole social structure. ${ }^{41}$ In her turn, Oliver uses Athelberht's Code as a framework upon which to hypothesize the function of other barbarian codes, thereby asserting that the code is typical of early Germanic legislation, and further that the Anglo-Saxon attitudes to mutilation represented in the code are not culturally distinct. ${ }^{42}$ Indeed, Oliver identifies Athelberht's Code as one of the earliest Germanic "personal injury tariffs," and suggests that Alfred the Great (871-899) promulgated the last comprehensive wergild in Western Europe c. 885 in a law-code known as domboc. ${ }^{43}$ This does seem to indicate that the Anglo-Saxons persisted with wergild as it was progressively abandoned on the continent, though interestingly neglects the wergild provisions of the Icelandic Grágás, first committed to writing in the twelfth century. ${ }^{44}$ The Grágás represent a difficult legal tradition to conceptualize as, in their written form, they represent three centuries of oral legal tradition that, while Norwegian in origin, evolved in the isolation of Iceland without the guidance of centralized administration. ${ }^{45}$ The late dating of the code is reflective of the late arrival of Christianity and literacy in Scandinavia, while giving evidence that, as in England, compensation for mutilation through wergild long remained the cultural norm in Scandinavia.

Like the Grágás of Iceland, the written law-codes of Anglo-Saxon England accompanied the arrival of Christianity. Athelberht's Code, for example, was written only five years after the arrival of Christian missionaries to Kent and codifies the rights of the church and compensation for their contravention. ${ }^{46}$ As such, the implementation of

\footnotetext{
${ }^{40}$ Ibid. 105-106, 108-109.

${ }^{41}$ Matthew Firth, "Allegories of Sight: Blinding and Power in Late Anglo-Saxon England," Cerae: An Australasian Journal of Medieval Studies 3 (2016) 2.

${ }^{42}$ Oliver, "Protecting the Body in Early Medieval Law," (n. 37 above) 70-76.

${ }^{43}$ Oliver, The Body Legal (n. 35 above) 14.

${ }^{44}$ Laws of Early Iceland: Grágas, the Codex Regius of Grágas, with material from other manuscripts, vol. 1, ed. and trans. Andrew Dennis, Peter Foote, and Richard Perkins (Winnipeg 1980).

45 Jesse Byock, Viking Age Iceland (London 2001) 309-319; Kristjánsson, Eddas and Sagas (n. 21 above) 117-120.

${ }^{46}$ Athelberht's Code 1 in Die Gesetze der Angelsachsen (n. 36 above) 3.
} 
just laws developed beyond the establishment of appropriate punitive and compensatory measures, to the codification of Christian ethics, amongst which was the sinner's need to find God's redemption. Within this context, the same factors that made mutilation such a grave crime also provided it with the potency to become an effective punishment in the law-codes of the tenth and eleventh centuries. Oliver notes that within medieval social structures, legally promulgated mutilation established "the material body as the medium for inscription of culpability and redemption." ${ }^{\prime 47}$ This is a point Katherine O'Brien O'Keeffe reiterates in her discussion of mutilation in late Anglo-Saxon England, stating of lawfully maimed criminals that "their mutilated bodies became texts of their behaviour and its lawful consequences." The point is threefold. Firstly, the mutilated body declares the criminal's misdeed; secondly, it is a didactic display of the results of crime; and thirdly, it becomes an alternative to capital punishment, allowing the criminal to redeem their soul before God. This last is indicative that, whatever they may preserve of pre-Christian tradition, written Anglo-Saxon law-codes were explicitly interwoven with Christian theologies of sin and the soul. Thus, as the body of the sinner emerged as a suitable vehicle for the didactic punishment of the law, punitive mutilation began to enter legislation.

In the century leading to Cnut's conquest, Anglo-Saxon legislators had already begun to introduce practical judicial torture into law. Alfred's domboc in the late ninth century implied that such measures may be deployed to punish oath-breakers at the discretion of a bishop: "let him there endure whatever penance the bishop determines for him. ${ }^{49}$ In turn, the c. 930 code II Ethelstan explicitly codified mutilation in mandating the punishment of dishonest moneyers: "if a moneyer is found guilty, the hand he used to commit the deed shall be cut off." ${ }^{, 50} V$ Athelred, composed in 1008, provides tacit approval of such practices in clause 3.1 by suggesting "life-sparing punishments be used" so as "not to destroy God's creations." "51 II Cnut 30.3-5,

\footnotetext{
${ }^{47}$ Richards, "The Body as Text" (n. 39 above) 97-98.

48 Katherine O'Brien O'Keeffe, "Body and Law in Late Anglo-Saxon England," Anglo-Saxon England 27 (1998) 217.

${ }^{49}$ Alfred domboc 1.2, in Die Gesetze der Angelsachsen (n. 36 above) 48.

${ }^{50}$ II Athelstan 14.1, in Die Gesetze der Angelsachsen (n. 36 above) 158

${ }^{51} V$ Athelred 3.1, in Die Gesetze der Angelsachsen (n. 36 above) 238.
} 
however, composed after 1020 , provides a specificity and structure to laws of punitive mutilation that are not evident in these earlier codes. Clause 30.3 provides a tiered penalty system in which the guilt of a thief is determined and appropriate fines and oaths undertaken in relation to the severity of his crime. ${ }^{52}$ While for the first offence the punishment is purely monetary, clause 30.4 allows for the recidivist thief to have "his hands or feet or both cut off, in correspondence with the crime. ${ }^{.53}$ In the unlikely event the mutilated criminal chooses to offend yet a third time, clause 30.5 then demands the incorrigible recidivist have "his eyes put out and his nose and ears and upper lip cut off, or his scalp removed." ${ }^{54}$ These clauses represent the most explicit codification of punitive mutilation in the Anglo-Saxon corpus to that date. Further, II Cnut is of note as a document that lies at a junction of two cultures. Authored for the Danish king by his predecessor Æthelred's advisor, Wulfstan Archbishop of York, Wulfstan's motivations are evident in the statement that "one can punish, and at the same time preserve the soul. ${ }^{, 55}$ Thus written by an Anglo-Saxon administrator, Cnut's laws ostensibly fell within native tradition and can be considered to have evolved from $V$ Athelred, also authored by Wulfstan. Yet it is necessary to question whether its inclusion at this point was indeed the result of evolving Anglo-Saxon legal cultures, or an intrusion of the Danish king's Scandinavian ideologies.

Interestingly, it is within hagiography that the clearest evidence that Cnut was working within Anglo-Saxon punitive traditions may be located. Excluding the ill-fated reign of King Edward the Martyr (975978), Anglo-Saxon England had remarkable stability in leadership from 943-1035, which facilitated legislative reform. As such, a significant number of law-codes survive not only from the reigns of Æthelred II and Cnut, but also from the reign of their predecessor Edgar I (959975), of whom there are four extant codes. ${ }^{56}$ While Edgar's laws

${ }^{52}$ II Cnut 30.3, in Die Gesetze der Angelsachsen (n. 36 above) 332.

${ }^{53}$ II Cnut 30.4, ibid.

${ }^{54}$ II Cnut 30.5, ibid.

55 Ibid.

56 Simon Keynes, "A Tale of Two Kings: Alfred the Great and Æthelred the Unready," Transactions of the Royal Historical Society 36 (1986) 212-213; Dorothy Whitelock, "Wulfstan Cantor and Anglo-Saxon Law," in Nordica Et Anglica: Studies in Honor of Stefan Einarsson, ed. Alan H. Orrick (The Hague 1968) 83-87; Wormald, The Making of English Law (n. 35 above) 126-127. 
provide little evidence of codified punitive mutilation, a passage from Translatio et miracula S. Swithuni set within Edgar's reign does describe the mutilation of an innocent man and the legal framework which informed the deed. In content, it is credible evidence of a formalized system of punitive mutilations existing prior to II Cnut:

A law of great severity was promulgated throughout England [...] if any thief or robber were to be found anywhere in the country, he would be tortured at length by having his eyes put out, his hands cut off, his ears torn off, his nostrils carved open and his feet removed. ${ }^{57}$

Commenting upon this passage as it appears in a poetic rendition of Translatio by Wulfstan Cantor, Dorothy Whitelock suggests that the extant law-codes from the reign of Edgar do not comprise a comprehensive view of his legislative program. ${ }^{58}$ Her further speculation that the similarities between the punishments of Translatio and II Cnut stem from the same fundamental religious concerns, thus reflecting the increasing involvement of the church in legislation throughout Edgar's reign, is plausible. The authorship of Translatio is near-contemporary with the reign of Edgar, thus any misattribution of Cnut's policies to Edgar can be dismissed. ${ }^{59}$ Supporting Whitelock's thesis, Simon Keynes argues that the implied reference to punitive mutilation in $V$ Ethelred's exhortation to "life-sparing punishments" represents a continuation of Edgar's legislative policies into Æthelred's reign, suggesting that Æthelred had no need to reissue the code. ${ }^{60}$ In other words, though $V$ Ethelred 3.1 does not explicitly detail the recommended tortures found in Translatio, it is nonetheless an authorization of legal mutilation as both punishment and spiritual mercy, and a direct link between the laws of Edgar and Cnut. That there is evidence for codified mutilation as an expression of both governmental legislative practices and Christian idealism does indicate

\footnotetext{
${ }^{57}$ Translatio et miracula S. Swithuni 26 (n. 32 above) 312-313.

${ }^{58}$ Whitelock, "Wulfstan Cantor" (n. 56 above) 85-86. Wulfstan Cantor is not to be confused with the aforementioned Wulfstan, Archbishop of York and royal adviser in the reigns of Æthelred and Cnut.

${ }^{59}$ Ibid. 86; Michael Lapidge, ed. and trans., The Cult of St Swithun (Oxford 2003) 6667.

${ }^{60}$ Keynes, "A Tale of Two Kings" (n. 56 above) 212. See also, Wormald, The Making of English Law (n. 35 above) 127.
} 
that the clauses in II Cnut are unlikely to have been innovations of the Danish King.

Within this context, it is important to note that the Grágás text postdates Cnut's reign by two centuries. Yet simply because the extant Scandinavian law-codes are comparatively late and continue to prescribe wergild, it does not hold that Scandinavian laws were primitive expressions of static Germanic law. They are a representation of a legal system that was active and evolving in the eleventh century, though unfortunately not committed to writing. However, it is because of the completeness of the Grágás at the point of their record that, in his analysis of the code, William Ian Miller elevates it above the "patchy and interstitial quality of Anglo-Saxon and continental barbarian codes," by virtue of "the range of its coverage and its detail within each area covered." ${ }^{.61}$ Of course, this is a comparison between laws that were recorded over five centuries in various states of evolution, and one that was written in the twelfth century as a fullyformed expression of an evolutionary process. A direct comparison of quality is neither genuinely possible, nor an advisable undertaking. Scandinavian law-codes demonstrate a living legal culture that evolved unique and comprehensive legislative programs in which wergild continued to hold a key role. The cultural reluctance to abandon wergild and feud paradigms does not subordinate Scandinavian law to an Anglo-Saxon system that is more familiar to modern sensibilities. Moreover, early Anglo-Saxon legislation such as Athelberht's Code predates direct Scandinavian cultural influence. Thus, when contrasted with the wergild provisions of later Scandinavian codes, the common origins of these laws become evident, as does the subsequent independent evolution of both Anglo-Saxon and Scandinavian legal traditions.

Yet the basic processes of the evolution of English and Scandinavian social values and legal structures were the samedifferences in the resulting law-codes attributable to the differing external influences and internal pressures faced by each society. In the case of evolving Anglo-Saxon attitudes to the body, as noted above, it seems these are more attributable to increased Christian influence over Anglo-Saxon legislation than any contact acculturation with

${ }^{61}$ Miller, Bloodtaking and Peacemaking (n. 3 above) 222. 
Scandinavians in England. ${ }^{62}$ This holds true of earlier AngloScandinavian interaction through viking raids and the Danelaw settlements, just as much as it does of Cnut's kingship. In c. 886 Alfred the Great and the viking leader Guthrum formalized the treaty that established the Danelaw and made formal recognition of regional rule by a Danish elite. ${ }^{63}$ Though the territory subsequently became a region of Scandinavian settlement, the population remained predominantly Anglo-Saxon. ${ }^{64}$ As a result, while the Danelaw retained a degree of Scandinavian cultural identity, it was diluted by a dominant AngloSaxon cultural identity (internally and externally). Æthelstan (924-939) reintegrated the Danelaw under the Anglo-Saxon crown in 927, while the 962 law-code of Edgar represents the last known official acknowledgement of the region's governmental independence: ${ }^{65}$

2.1 And it is my will that secular rights be in force among the Danes according to as good laws as they can best decide on. ${ }^{66}$

Thus the Danelaw operated as an independent polity for less than a century, and its rapid cultural assimilation results in part from an even more expeditious Christianization: Guthrum accepted baptism at the behest of Alfred in 878 and, by the late ninth century, most Danelaw elites had converted. ${ }^{67}$ Scandinavian law-codes reference a more tenacious pagan identity across the North Sea. The thirteenth-century Uppland Law of central Sweden, for example, despite Christian

${ }^{62}$ Daniela Fruscione, "Beginnings and Legitimation of Punishment in Early AngloSaxon Legislation from the Seventh to the Ninth Century," in Capital and Corporal Punishment in Anglo-Saxon England, ed. Jay Paul Gates and Nicole Marafioti (Woodbridge 2014) 36.

${ }^{63}$ Alfred - Guthrum Treaty, in Die Gesetze der Angelsachsen (n. 36 above) 126-128; ASC A 886 (n. 2 above) 80.

${ }^{64}$ Katherine Holman, The Northern Conquest: Vikings in Britain and Ireland (Oxford 2007) 97-99.

${ }^{65}$ ASC D 926 (n. 2 above) 105; Holman, The Northern Conquest (n. 64 above) 163. It is of note that the Danelaw continued to be identifiable in law-codes that postdate $I V$ Edgar, such as III Ethelred (c. 997), as a culturally distinctive region; however, after IV Edgar these assert the direct control of the Anglo-Saxon crown. III AEthelred 1.1-1.2, in Die Gesetze der Angelsachsen (n. 36 above) 228.

${ }^{66}$ IV Edgar 2.1, in Die Gesetze der Angelsachsen (n. 36 above) 210. English translation from Dorothy Whitelock, ed., English Historical Documents, vol. 1 (London 1979) 435.

${ }^{67}$ ASC A 878 (n. 2 above) 74-76; Angelo Forte, Richard Oram and Frederik Pedersen, Viking Empires (Cambridge 2005) 77-78. 
authorship (or collation), is explicit in asserting the value of laws created by earlier pagan legislators, recording inherited law and Christian law as independent traditions:

Thus gives the sovereign king...to all of them, who live between the sea and Sagå river and Ödmorden, this book, which contains Vigher's flokkr and Upplandic law [which] Lawmaker was Vigher the wise, pagan in pagan time. What we find in his law which is for the benefit for all, we include; that which is useless we will exclude. And everything which the pagan has not included, hence the Christian law and the Church law, we shall add to the beginning. ${ }^{68}$

In their turn, though lacking the self-reflective preface of the Uppland Law, the Grágás demonstrate a similarly prosaic approach to the codification of pre-existing, pre-Christian laws. Indeed, the Grágás are remarkably reticent on matters of religion, also maintaining Christian laws as a separate set of clauses and venerating the laws of earlier generations including compensatory clauses that would have been unremarkable in seventh-century England. ${ }^{69}$ The similarities between ninth-century Anglo-Saxon law and twelfth-century Scandinavian law are firmly attributable to a common cultural heritage.

\section{PUNITIVE MUTILATION AND ÍSLENDINGASÖGUR}

Culminating in Cnut's 1016 conquest of England, the three-hundred years of direct cultural contact between the Anglo-Saxons and Scandinavians is characterized by the incursion of viking invaders and settlers on English shores. Thus, while Anglo-Saxon culture may have adopted Scandinavian societal attitudes to punitive mutilation, it is unlikely that the opposite is true. It is plausible, therefore, to suggest that Scandinavian influences can be detected in the evolution of AngloSaxon attitudes to punitive mutilation within native English literature. Yet it is worth noting that, with large numbers of Scandinavians travelling to the British Isles from the eighth to eleventh centuries, England is not ignored within the sagas, and there is some value in briefly considering the degree to which saga literature, both narrative

${ }^{68}$ Uppland Law, trans. Stefan Brink, extract in Stefan Brink, "The Creation of a Scandinavian Provincial Law: How was it done?" Historical Research 86, iss. 233 (2013) 436.

${ }^{69}$ Grágas, vol. 1, K1-19 for Christian laws, K86, K113-115 for legal provisions for woundings, deaths or attempts at either (n. 44 above) 23-52, 139-143, 175-184. 
and verse, can be read as a source of English history. It is a topic that has received some significant attention. The distance of saga prose and skaldic verse from the events they purport to relate mean that they do need to be treated with caution. As Alistair Campbell has noted "no Icelandic saga is older than the twelfth century, but while the verses a saga quotes may be no older than itself, they may be much older, and indeed may be of the period of the events to which they seem to refer." ${ }^{, 70}$ Gabrielle Turville-Petre perhaps more succinctly declared that "skaldic verse can tell us little about the history of England, but the history of England may give us confidence in the authenticity of some skaldic verses." ${ }^{, 71}$ In drawing on both of these scholars, Russell Poole gives extensive consideration to the historicity of skaldic verse, particularly in the light of verses relating Cnut's English conquest, concluding that while it is true such sources are best analysed in the light of Anglo-Saxon texts, they do allow the perspicacious reader to engage in plausible speculation. ${ }^{72}$ It is with this in mind that Íslendingasögur have been classified as narrative alongside AngloLatin hagiography, for, while both provide markers for accepted cultural practice, both also provide only a rough sketch of the historical realities of any specific event.

Selecting occasions of torture from Íslendingasögur for examination is not difficult - the scarcity of torture motifs means that those that exist are immediately evident. The reluctance of saga authors to employ the topos of punitive mutilation seems to indicate that such acts sit outside legal and social norms. ${ }^{73}$ Though acts of torture are always located within a legal and social framework, they are universally extrajuridical, perpetuating cycles of revenge during which, as Hall states, "nothing good comes to the torturer.", Though acts of deliberate mutilation are conspicuous within the corpus, they are equally notable for an attendant economy in imagery, characteristic both of the stylistic

\footnotetext{
${ }^{70}$ Alistair Campbell, Skaldic Verse and Anglo-Saxon History (London 1970) 3.

${ }^{71}$ E. O. G. Turville-Petre, Scaldic Poetry (Oxford 1976) lxx.

${ }^{72}$ Russell Poole, "Skaldic Verse and Anglo-Saxon History: Some Aspects of the Period 1009-1016," Speculum 62, iss. 2 (1987) 265-267, 298.

${ }^{73}$ Hall, "Last Laughs" (n. 25 above) 98; Tracy, Torture and Brutality (n. 19 above) $128-129$.

${ }^{74}$ Hall, "Last Laughs" (n. 25 above) 98.
} 
brevity of saga literature, and the didactic intent of the trope ${ }^{75}$ Within saga, the narrative focus of a mutilation motif usually falls upon the torturer who is portrayed as a danger to social normativity and a perpetuator of feud, while within hagiography the focus is upon the victim, who is also a challenge to social normativity, but as a paradigm of godly virtue rejected by the world. ${ }^{76}$ In the latter case the violence of that rejection only serves to amplify the saint's piety and thus the didactic impact of saintly torture resides within the brutal descriptions of the saint's bodily suffering. ${ }^{77}$ While in the former case to dwell unnecessarily upon an individual's experience of mutilation would be to dilute the motif's intent to decry the inconclusive outcomes of extrajuridical justice and its negative impact of the function of society. ${ }^{78}$

Turning then to specific examples of punitive mutilation in saga literature, the unique style and concision of expression ubiquitous to the sagas are best observed comparatively. Thus, though two of the following episodes have been previously noted, it is worth providing them again in full. Firstly, the evisceration of Broðir, of which, setting aside the context surrounding the event, the Njáls saga author states:

Úlf Hræða cut open his belly and led him around an oak tree and in this way pulled out his intestines. Broðir did not die until they were all pulled out of him. $^{79}$

Secondly, the torture of Hrafnkel and his men in Hrafnkels saga Freysgoða is described thus:

Then they took out their knives, pierced holes through the men's heels behind the tendons, and dragged the ropes through these holes. They threw the rope over the beam, and strung the eight of them up together. ${ }^{80}$

${ }^{75}$ Pórir Óskarsson, "Rhetoric and Style," in Old Norse-Iceland Literature (n. 21 above) 364

${ }^{76}$ Robert Bartlett, Why Can the Dead do Such Great Things? Saints and Worshippers from the Martyrs to the Reformation (Princeton 2013) 174-176, 184; Fulk, "The Moral System of Hrafnkels saga Freysgoða" (n. 31 above) 22-23.

${ }^{77}$ Tracy, Torture and Brutality (n. 19 above) 31-35; Rolf H. Bremmer Jr., "Shame and Honour in Ælfric's Lives of Saints," in Hagiography in Anglo-Saxon England: Adopting and Adapting Saints' Lives into Old English Prose, c. 950-1150, ed. Loredana Lazzari, Patrizia Lendinara, and Claudia di Sciacca (Barcelona 2014) 118-119.

78 Jan Geir Johansen, "The Hero of 'Hrafnkels Saga Freysgoða'," Scandinavian Studies 67, iss. 3 (1995) 281-282.

${ }^{79}$ Brennu-Njáls saga 157 (n. 11 above) 453; Njal's saga 167 (n. 11 above) 214.

${ }^{80}$ Hrafnkels saga Freysgoða 5 (n. 30 above) 120. 
Lastly is an obscure non-sequitur which forms a part of a feud cycle in Gunnlaugs saga Ormstungu, and which, by virtue of its dry delivery and neutral tone, may in fact indicate that there were circumstances in which extra-juridical punitive mutilation may have been an acceptable course of action:

...Illugi seized two of [Qnund's] kinsmen, one called Bjorn and the other Thorgrím. Illugi had Björn killed and Thorgrím's foot cut off. ${ }^{81}$

This is an act of revenge, driven by the treacherous slaying of the eponymous character in a duel: in a moment of vulnerability Gunnlaug's opponent, Hrafn, contrary to his oath, strikes at Gunnlaug's head and deals him a mortal wound. ${ }^{82}$ It is in the pursuit of vengeance for this slaying that Gunnlaug's father, Illugi, captured Hrafn's kinsmen, Björn and Thorgrim, killing the former and mutilating the latter. Unusually, these actions end the feud between the families; the saga author notes that Hrafn's father "made no reprisal." ${ }^{83}$ It seems likely that this is in part due to Hrafn's actions in the duel providing Illugi legal justification under Icelandic law to seek vengeance, though the Grágás only codify dispensations for reciprocal killings; the amputation of Thorgrim's foot has no legal basis. ${ }^{84}$ It does, however, have hagiographical precedent. The loss of the foot itself is quite unique, but mutilation or the deprivation of function as vengeance is an idea that appears throughout the Anglo-Latin hagiographical corpus from the earliest texts.

Underlying this analysis is the presumption that the vengeance motif is a genuine preservation of social mores from Anglo-Saxon and early medieval Scandinavian societies. Yet it may also be that the trope reflects how hagiographers believed earlier societies operated, and whether this precludes the motif being a genuine cultural memory warrants some consideration. Certainly there is an intrusion of hagiography into saga literature in the evisceration of Broðir as established by Frankis. ${ }^{85}$ Broðir's fatal walk is a mode of death also

\footnotetext{
${ }^{81}$ Gunnlaugs saga Ormstungu - The Story of Gunnlaug Serpent-tongue 13, ed. P. G. Foote, trans. R. Quirk (London 1957) 39.

${ }^{82}$ Ibid. 12.

${ }^{83}$ Ibid. 13

${ }^{84}$ Grágas, vol. 1, K87 (n. 44 above) 147.

${ }^{85}$ Frankis, "From Saint's Life to Saga" (n. 8 above) 123-127.
} 
found in Gaimar's account of Alfred AEtheling's martyrdom, an event of such political importance as to warrant extensive record in annals that predate that narrative, none of which note the atheling's evisceration. ${ }^{86}$ Neither do medieval Irish chronicles or annals make mention of Broðir's evisceration in the aftermath of the Battle of Clontarf. ${ }^{87}$ As Frankis suggests, in detail, the fatal walk is likely "hagiographical fantasy." ${ }^{, 88}$ However, there is little reason to doubt the place of a mutilation motif within the narrative as something contemporaneous with the story it told. Alfred's blinding is an element in the accounts of his death from their earliest redactions and, in Gaimar, the fatal walk is simply added to it, though the torture motif still performs the same basic literary function. ${ }^{89}$ That the saint-figure underwent an ordeal was known, whether the detail of that ordeal was forgotten or embellished does not negate the motif as a preservation of oral memory. Likewise, it is not unreasonable to presume that a man who had killed the Irish king, as Broðir purportedly did, would suffer a brutal reprisal that grew in the telling, with the fatal walk providing the Njáls saga author a convenient and suitably gruesome tableau. ${ }^{90}$ However, this dichotomy of fantastic torture and social realism is most clearly evident in Hrafnkels saga. The torture of Hrafnkel and his men is unusual in form and a likely logistic impossibility. Importantly, however, Hrafnkel is not killed and as such, though stripped of possession and titles, he is later able to enact revenge by bankrupting his antagonist and killing his brother. ${ }^{91}$ It is a believable narrative in a society that allowed a shamed or maltreated man the recourse of feud justice; once again the details of the torture give the impression of

${ }^{86}$ Geffrei Gaimar, Estoire des Engleis 4819-4842 (n. 10 above) 263. Accounts of Alfred's mutilation that exclude the fatal walk include: ASC C 1036 (n. 2 above) 158159; The Chronicle of John of Worcester: The Annals from 450-1066 1036, ed. R.R. Darlington and P. McGurk, trans. Jennifer Bray and P. McGurk, vol. 2 (Oxford 1995) 522-525; Encomium Emmae Reginae ii.6, ed. Alistair Campbell, reprint (Cambridge 1998 [1949]) 42-43; William of Malmesbury, G.Reg ii.188.5-6 (n. 15 above) 336-339. Frankis, "From Saint's Life to Saga" (n. 8 above) 124.

${ }^{87}$ See for example: The Annals of Ulster (To AD 1131) 1014, ed. Seán Mac Airt and Gearóid Mac Niocaill (Dublin 1983) 446-451.

${ }^{88}$ Frankis, "From Saint's Life to Saga" (n. 8 above) 124.

${ }^{89}$ ASC C 1036 (n. 2 above) 158-159; The Chronicle of John of Worcester 1036 (n. 86 above) 522-525; Encomium Emmae Reginae ii.6 (n. 86 above) 42-43; William of Malmesbury, G.Reg ii.188.5-6 (n. 15 above) 336-339.

${ }^{90}$ Brennu-Njáls saga 157 (n. 11 above) 453.

${ }^{91}$ Hrafnkels saga Freysgoða 8 (n. 30 above) 126-127. 
authorial invention, yet the fundamental role of the torture provides a credible social commentary.

Punitive Mutilation AND THE Lives of ANGLO-SAXON SAINTS Granted the violence of the viking raids that preceded Cnut's reign and the political unrest that followed it, it is unsurprising that the antagonists of numerous Anglo-Saxon saints' lives set within that milieu are Scandinavian and, at times, pagan. The otherness of an antagonist is a useful tool for a hagiographer, for the foreign nature of the torturer and their existence outside of right belief serves to enhance the unnatural nature of the torture motif. ${ }^{92}$ King Edmund of East Anglia for example, was reputedly martyred in 869 by vikings who demanded he renounce Christ. In his description of the event composed c. 1000, Elfric details the brutality with which the invaders treated the "holy Edmund":

...dishonourable men bound Edmund and mocked him shamefully and beat him with staffs. Then afterwards they led the faithful king to a sturdy tree and tied him to it with firm chains, and again beat him with whips for a long time...They then shot at him with missiles too...until he was entirely covered with their missiles... as Sebastian was. When Hinguar, the cruel viking, saw that the noble king would not forsake Christ... with one blow they struck off his head, and his happy soul journeyed to Christ. ${ }^{93}$

The intertextual motifs here are notable: the beatings and the mocking reminiscent of Christ's passion, the king peppered with arrows (or spears) a borrowing from the martyrdom of St Sebastian, as Ælfric notes. ${ }^{94}$ Following these models, the contrast between protagonist and antagonist is explicit, the martyred king is treated with effusion, the cruelty and foreignness of his tormentors emphasized. A similar narrative structure, and the use of similar motifs, can be identified in accounts of the murder of Ælfheah, the archbishop of Canterbury in 1012. Though intertextuality in this narrative is rather more implicit

92 Tracy, Torture and Brutality (n. 19 above) 35-36.

${ }^{93}$ Passio Sancti Edmundi Regis et Martyris, in $O \& M E$ (n. 3 above) 148-149.

${ }^{94}$ Matthew 19:26-50; Mark 15:16-38; Luke 23:25-46; John 19:1-5, 28-30; James W. Earl, "Violence and Non-Violence in Anglo-Saxon England: Ælfric's 'Passion of St. Edmund," Philological Quarterly, 78 (1999) 128-130; Antonia Gransden, "The legends and traditions concerning the origins of the Abbey of Bury St Edmunds," English Historical Review 100, iss. 394 (1985) 6-7. 
than in Edmund's passio, when the two accounts are read comparatively the parallels are evident. Held for ransom by a viking raiding party, the Chronicle recounts Ælfheah's fate:

Then on the Saturday the army became greatly incensed against the bishop because he would not promise them any money, but forbade that anything should be paid for him... They seized the bishop, and brought him to their assembly....and shamefully put him to death there: they pelted him with bones and with ox-heads, and one of them struck him on the head with the back of an axe... his holy blood fell on the ground, and so he sent his holy soul to God's kingdom. ${ }^{95}$

While Edmund's death was a traditional martyrdom in defence of faith, the religious aspects of Ælfheah's martyrdom are tempered by political concerns. Indeed, his qualification as a martyr was questioned in the post-Conquest church, his death interpretable as having derived from a dispute over the terms of his release, not in defence of his faith. ${ }^{96}$ It is for this reason, the purely political nature of the deed, that Alfred Ætheling was never canonized after his assassination. The pseudo-saint was killed by Godwin in support of Cnut's successors as claimants to the throne; in every narrative the prince is blinded and then dies, with the fatal walk a later adaptation. ${ }^{97}$ Each man bears his torture with stoicism and the hagiographers do not allow their protagonists to be anything but noble and defiant in the face of their inevitable death.

Seeking evidence for cultural attitudes to punitive mutilation in such motifs can be difficult. The adaptation of punitive mutilation within the sagas examined above is at once a more nuanced use of the trope than seen in the passiones of Edmund, Ælfheah, and Alfred, and better fits the definition of punitive mutilation as both retributive and intentional. The torture of an innocent is a universal story element within hagiography and is not restricted to Anglo-Saxon texts. The stoic saint bearing pain and death for the glory of God has its narrative genesis in

${ }^{95}$ ASC C-E 1012 (n. 2 above) 142-143; see also: Henry of Huntingdon, Historia Anglorum: The History of the English People v.5, ed. and trans. Diana E. Greenaway (Oxford 1996) 350-351; The Chronicle of John of Worcester, 1012 (n. 86 above) 470471.

${ }^{96}$ Alexander R. Rumble, "From Winchester to Canterbury: Ælfheah and StigandBishops, Archbishops and Victims," in Leaders of the Anglo-Saxon Church: From Bede to Stigand, ed. Alexander R. Rumble (Woodbridge 2012) 170-173.

${ }^{97}$ ASC C 1036 (n. 2 above) 158-159; The Chronicle of John of Worcester 1036 (n. 86 above) 522-525; Encomium Emmae Reginae ii.6-7 (n. 86 above) 42-47. 
Christ's own trial and crucifixion, manifesting in the passio hagiographical type, prevalent throughout all regions of Christendom. The saint's murder is the focus of the passiones and, as such, torture is not necessary to the construction of the narrative-decollation in the mould of John the Baptist's death is a more frequent motif though, as in the case of Edmund, the two can be combined. ${ }^{98}$ Nonetheless, in his scourging and humiliation Christ is the precedent for the topos of the brutalized martyr and, in hagiographical narrative, such deprivation serves to enhance the contrast between the virtuous saint and the wicked torturer. However, such narrative devices are always transmitted through a cultural lens, and these hagiographies are not simply undifferentiated narrative frameworks into which hagiographers insert tropes relevant to their didactic intent. They are products of the political and social milieu in which the narrative was located, or at least later perceptions of those factors. ${ }^{99}$ The Anglo-Saxon experience of Scandinavians in the period in which the martyrdoms of Edmund, Ælfheah, and Alfred are set ensured that vikings and their sympathizers were cast into the roles of murderer and torturer. ${ }^{100}$ The righteous saint is deliberately juxtaposed against the otherness of the vikings as a technique to enhance that righteousness: violent men existing outside of God's grace and the social and religious structures of Christian England are confronted by the paradigm expression of that grace and order.

The otherness of the vikings in these narratives make it unlikely that any conscious borrowing was made from Norse traditions. Moreover, the passiones of Edmund, Ælfheah, and Alfred were not composed for a Scandinavian audience. These are specifically Anglo-Saxon characters, eulogized in part for their political agency within that context, while the earliest extent text (Abbo of Fleury's Passio Sancti Eadmundi) dates to around thirty years before Cnut's conquest and the installation of a new Scandinavian elite. Any similarity between AngloSaxon and Scandinavian literary traditions relating to the topos of punitive mutilation is far more likely to stem either from prolonged

\footnotetext{
${ }^{98}$ Matthew 14:1-10; Mark 6:21-29; Rachel S. Anderson, "Saints' Legends," in A History of Old English Literature, ed. R.D. Faulk and Christopher M. Cain (Oxford 2005) 86.

${ }^{99}$ Cubitt, "Sites and Sanctity" (n. 5 above) 67.

${ }^{100}$ See for example: Roger of Wendover's Flowers of History 870, 1011, 1036, ed. and trans. J. A. Giles, vol. 1 (London 1849) 198-199, 278-280, 301.
} 
cultural contact or a common cultural heritage. The former provides a number of barriers as an explanation. In the period these saints' lives and sagas recall, the English and the Scandinavians were religiously and linguistically divided, and this dynamic holds true to varying degrees in regards to the contact between the cultures in the Danelaw between the eighth and tenth centuries. ${ }^{101}$ The sagas clearly consider Anglo-Saxon England to be a part of the Scandinavian world with numerous saga heroes venturing to the island; however, as Magnús Fjalldal has concluded, any mutual intelligibility between Old English and Old Norse is unable to be determined. ${ }^{102}$ The linguistic impediment to oral transmission, combined with the basic incompatibility of religious aspects of the narratives reinforces the improbability of conscious narrative borrowings. Further, the textual record of these narratives was made at an even wider political and geographical divide despite the universal Christianity of the scribes: the hagiographies of Anglo-Saxon saints were primarily recorded in Norman England while the sagas were largely composed in Iceland. ${ }^{103}$ Nonetheless, the motif of punitive mutilation is present in saga literature and, similar to the defiant saints, the tortured saga hero bears his tribulations with stoicism.

Punitive miracles entailing the deprivation of function are not exclusive to the lives of Anglo-Saxon saints, yet they are prevalent within them. ${ }^{104}$ Though the evolution of legal codes demonstrated a decline in feud as a characteristic of Anglo-Saxon society into the tenth century, it remains that, as exemplified by Ethelberht's Code, feud cycles were endemic within Anglo-Saxon culture, requiring legal intervention to thwart their perpetuation. ${ }^{105}$ Therefore, it is not surprising that the saints of Anglo-Saxon England seek posthumous retributive justice against their aggressors. Such acts of mutilation are

\footnotetext{
${ }^{101}$ Forte et al., Viking Empires (n. 67 above) 77-80; Magnús Fjalldal, Anglo-Saxon England in Icelandic Medieval Texts (Toronto 2005) 5-8.

${ }^{102}$ Fjalldal, Anglo-Saxon England (n. 101 above) 8-11. Though numerous saga figures spend time in England, the most famous traveller is Egil Skallagrimmson, though his adventures with the kings of the British Isles are clearly fiction, Egils saga 50-55, ed. Bjarni Einarsson (London 2003) 71-84.

${ }^{103}$ Kristjánsson, Eddas and Sagas (n. 21 above) 21-24.

${ }^{104}$ Bartlett, Why Can the Dead do Such Great Things? (n. 76 above) 401-409.

${ }_{105}$ See for example: Ethelberht's Code 8, 42-44, 79-81 in Die Gesetze der Angelsachsen (n. 36 above) 3-8.
} 
of narrative importance as didactic motifs and evidence of cultural values; they are a demonstration of the saint's spiritual agency; they fulfil a cultural appetite to see retributive justice enacted on the unjust; and they provide evidence that such an appetite did indeed exist. ${ }^{106}$ Bede gives an early example of the deprivation of function as a retributive topos in his eighth-century Historia ecclesiastica. Narrating the martyrdom of St. Alban, Bede recounts the divine vengeance for the saint's beheading: that "as the martyr's head fell, the executioner's eyes

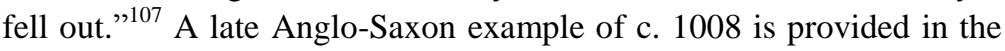
earliest hagiographical account of the murder of King Edward the Martyr which was included by Byrhtferth of Ramsey in the Vita S. Oswaldi. The young king, eulogized by the hagiographer and cast as a martyr, was murdered by disloyal thegns seeking to place his more compliant younger brother on the throne. In the aftermath of the event, the hagiographer narrates God's retribution on one of the perpetrators in a trope clearly derived from Bede's account of St Alban's martyrdom.

One of them endured a semblance of punishment so that he lost both his eyes and suffered an inexpressible deprivation of both his visions-I mean the loss of sight in this life as well as the next! ${ }^{108}$

In its turn, the late eleventh-century Vita et Miracula S. Kenelmi, reflecting back upon an Anglo-Saxon world which was perhaps becoming culturally distant, provides a litany of vengeful acts depriving function, all acts of retribution for disrespecting the saint's cult. Kenelm's treacherous sister's eyes were "rooted out from their sockets" as she tried to curse his memory; a similar fate befell a merchant-woman who encouraged others to work on the saint's feast, whose "eyes shot out on to the table"; a man who swore to an untrue testimony in Kenelm's name was "struck dumb"; during Cnut's reign a rapacious Dane who attempted to annex church land under the saint's protection was driven "seemingly out of his mind" and "did not survive

${ }^{106}$ Tracy, Torture and Brutality (n. 19 above) 31-35.

${ }^{107}$ Bede, Ecclesiastical History 1.vii (n. 2 above) 28-35.

${ }^{108}$ Byrhtferth of Ramsey, Vita S. Oswaldi iv. 18-20, in The Lives of St Oswald and St Ecgwine, ed. and trans. Michael Lapidge (Oxford 2009) 137-143. For a more detailed discussion of the repeated motif of blinding in Anglo-Saxon hagiography, see Firth, "Allegories of Sight" (n. 41 above) 2-28. 
for long afterwards." ${ }^{, 109}$ Kenelm is almost extraordinarily vindictive, likely representing an Anglo-Norman conception of the nature of Anglo-Saxon society, and the Vita et Miracula narrates numerous other punitive miracles as the motif of mutilation as vengeance is made explicit. In Anglo-Saxon hagiography the forbearance of the saint in the face of his tribulations does not represent a fully realized motif: cultural principles demanded vengeance for wrongs done. ${ }^{110}$ Alban, Edward, and Kenelm become the vehicle for torture rather than the tortured exemplar and, in this expression of the trope, it can be seen that the need to enact vengeance for an unlawful killing is no less in AngloSaxon saints' lives than in Íslendingasögur. This displays a cultural attitude to punitive mutilation similar to that in evidence in late AngloSaxon law-codes. If the form of this punishment was mutilation rather than death, the power of the perpetrator, whether saint or saga hero, is inscribed on his victims' bodies, forever advertising their wrongs and displaying the cost of them. Though the specifics of literary expressions of punitive mutilation may represent later additions and inter-cultural borrowings, the narrative spaces they fill evolved independently and parallel within their cultures as expressions of common social norms born of a common heritage.

\section{CONCLUSION}

Reflecting upon Cnut's conquest of England, M. K. Lawson states that "a common Germanic background must often have rendered AngloScandinavian fusion easy." "111 Indeed, that common Germanic background is the key element explaining common Anglo-Saxon and Scandinavian cultural attitudes toward punitive mutilation, but it is not the only factor. The stated aim of this analysis was to determine whether the similarity of attitude to punitive mutilation in the eleventhcentury Anglo-Scandinavian world stemmed from that shared Germanic heritage, from contact acculturation, or the annexation of England into Cnut's hegemony. It is not possible to entirely dismiss any of these elements in the formation of cultural attitudes, yet some

109 Vita et miracula S. Kenelmi 16-21, in Three Eleventh-Century Anglo-Saxon Saints' Lives, ed. and trans. Rosalind C. Love (Oxford 1996) 70-79.

${ }^{110}$ Cubitt, "Sites and Sanctity" (n. 5 above) 70-72.

${ }^{111}$ M.K. Lawson, Cnut: England's Viking King, 1016-1035, 3rd ed. (London 2011) 13. 
factors are more prevalent than others. Despite their close cultural contact through Danish settlement and Cnut's kingship, Anglo-Saxon England did not experience a significant assimilation of Scandinavian societal attitudes throughout the eleventh century. It was the Danish settlers who assimilated with their Anglo-Saxon neighbours, the Danish king who sought to mould himself to Anglo-Saxon cultural expectations. While both undoubtedly had some influence upon AngloSaxon social mores, the mores that both societies held in common are explicable by common heritage. Twelfth-century Scandinavian lawcodes preserve legal models abandoned two centuries earlier in England; pagan saga-characters and Christian saints both bear their tortures with stoicism. Acculturation and imposition cannot fully explain how the topos of mutilative vengeance comes to permeate such varied Anglo-Scandinavian sources: attitudes to punitive mutilation represent older social memory.

That shared hagiographical elements of punitive mutilation appear both in the religious biographies of Anglo-Saxon England and Íslendingasögur is not remarkable. Despite their narrative disparities, the framework of authorship for both corpora was commensurate. The authors were Christians, familiar with the textual traditions of church literature of their time, who accessed the language and motifs of that tradition. Yet Christianity was both a unifying and differentiating influence within Anglo-Scandinavian sources as both regions had different experiences of Christianization. In contrast to Anglo-Saxon England, Christianity and literacy were late-comers to Scandinavia and, while Christian tenets permeate the Scandinavian sources, the cultural attitudes to punitive mutilation on display in them reflect upon a preChristian past. The cultural familiarity between Anglo-Saxon and Scandinavian traditions exemplified in attitudes to the mutilation of the body cannot be attributed to a common religion alone, for they did not share a common religion for three centuries. Both cultural traditions may demonstrate a commensurate desire for justly inflicted vengeance in their law-codes and narratives, yet these are legal and literary traditions that evolved parallel and independently. The laws and narratives of eleventh-thirteenth-century England and Scandinavia each display a cultural familiarity with acts of punitive mutilation primarily because both cultures shared common societal values born of a common Germanic cultural heritage. 